\title{
The impact of Albanian schools in the Nation-building process
}

\author{
Lulzim Hoxha \\ European University of Tirana, Albania \\ E-mail: lulzimhoxha_uet@yahoo.com;
}

Abstract

Education is often perceived as an individual will of citizens to become part of the social edifice, in which they learn the history of their ancestors and their country despite of the political sphere. In this paper l'll try to argue that not only education isn't an independent category of knowledge, but also that the whole process of learning is marked and shaped by a given political goal, namely the construction of a solid social space which defines our political identity as members of a community. A further study of the historical contexts in which education gave birth to a unified social community will give an answer to the issue if education is a field deprived of any political argument but only objective truths, or if this field performs specific functions to unify a functionally divided society and its mission comes from outside the education system. This issue will be treated through a comparative analysis between two opposite scholars of nationalism such as Isa Blumi and Denisa Kostovicova. Firstly l'll try to argue the impact of schools and mass education on the construction of national myths from the perspective of the contemporary theories of nationalism which will be explained in the discussion between the primordialist (learning has always existed and it contains historical truths despite of the political sphere with the final mission of nationally promoting mother tongue) and the instrumentalist (learning is shaped as a political instrument with a specific function) viewpoint.

Keywords: Nationalism, Ideology, Constructivism, Education

\section{Language and education in the performing of nationalist propaganda}

The contemporary theories of nationalism focus on the idea that nation as a social community has been constructed by the nationalist propaganda of the renaissance, which has politicized certain elements such as language, religion, culture in view of the changing realities of that time. According to Eric Hobsbawm "Mass education is one of the crucial factors that influenced the creation of national identity" (Hobsbawm: 1992). To illustrate his assumption, he takes the example of Italy where before the foundation of the Italian state in the XIX century, Italian language was spoken only by the privileged social strata which made about $2.5 \%$ of the whole country. By unifying the new community formed under the effect of the national discourse, mass education integrates all the differences that exist in society by reproducing a large scale of unification through the written national language newspapers and. Even in such multicultural states as the Ottoman empire or the state of Yugoslavia, respectively the ottoman language (which differs from the Turkish language of our times) and the Serbian language were both national languages, thus citizens were obliged to learn these language despite of their ethnicity to become part of society, especially in the Ottoman empire where language marked the social hierarchy of people. Albanian language was banned and for several years it remained limited only as oral speech. Professor Albert Doja remarks that "the main argument of the Ottoman state to ban the organization of learning in Albanian language was that Albanians belonged to different religious communities such as Muslims, Orthodox and Catholics. Language was even more important for Albanian population because since they couldn't rely on their religious identity, language became the main instrument of Albanian national identity" (Doja: 2009). For this purpose the setting-up of a school where could be learned Albanian language was of crucial importance for the political aspirations of Albanian national identity.

The same phenomenon can be remarked in Kosovo Albanians under the rule of the Yugoslavian state. The setting-up of the Albanian University in Pristina in 1968 immediately became an important political instrument for "Albanian nationalist discontent simmered throughout the 1970s, with Pristina University becoming a breeding ground for nationalists" (Poulton: 1997) The first proclamations for unification with Albania came exactly after the foundation of the University of Pristina, where in 1981 a large protest exploded with a massive wave of unrest in Kosovo sparked off by University students. University was transformed in a political tool for articulating people's national appurtenance.

Even in Europe we can find the nationalist discourse articulated by the romantic writers, intellectuals and political elites that rooted and spread the concept of people's sovereignty. Firstly, the rationalist scientific revolution of XVI century encouraged the intellectuals to study the fundamental laws and notions of the universe and humanity. Therefore, man was put in the center of the universe and was endowed by inherent and inalienable values, underlying today's doctrine of universal human 
rights. The next step was the legitimacy of power through the approval of the rule of the sovereign by the citizens. This process was completed by the XVIII and XIX century political philosophy, political theories and classical sociology with social theorists such as Max Weber, Kant, Marx or Montesquieu etc that altogether produced and also invented what we know in our days as the basic features of society and human beings. Especially with Max Weber's principles of legitimate power it is shaped the profile of legitimacy despite of the form in which the ruler decides to perform his political power whether "charismatic, traditional or legal rational". Thus, it was founded the issue of the identification of all the citizens into a cultural community with a given state, which now appeared as the institutional tool of exercising people's or nation's will. The reproduction of these new rational principles were performed through the rejection of despotism, which in other words meant the rejection of the past and also the rejection of Oriental cultures, which according to Marx they were symbols of Europe's past. One of the most cited political theorists that is still very popular in contemporary philosophical debates is Montesquieu, which in his most known book "The spirit of laws" writes: "Under despotism, man is a creature that blindly submits to the absolute will of the sovereign." In democratic monarchies, moderate states power was limited by restrictions. A monarch may have as much power as a despot but in a moderate, monarchical system the prince "receives instruction", and he chooses ministers more competent than in despotic systems" (Anne Cohler: 1988) ${ }^{1}$. Thus we can say that philosophical knowledge gave a fundamental contribution not only on explaining the legitimacy of power and politics but also in rationalizing and structuring a knowledge which served as a political instrument to demarcate a specific cultural area (the developed and rational west) from other cultural areas (the Orient as backward and irrational) and historical spaces (the past as a symbol of backwardness). The activity of the discovery of the historical past and other cultural areas took the shape of a Pan-European cultural movement which lasted from XVIII to the XIX centuries, through which were "discovered" the ancestors of nations were invented national literary languages and were developed the histories and myths of specific nations (Thiesse, 2004). Nonetheless this process of invention shouldn't be conceived as an artificial process, because what these intellectuals effectively did was inserting in the category of objective knowledge, several traditions transmitted verbally. As Enis Sulstarova puts it:

What the intellectuals did was the organization of the past and cultural heritage of populations in order to increase the political mobilization for the foundation of national states. The writing of some languages that were till that time only spoken and also the mass education were considered by them as the most important instruments for embedded and the spread of the national imagination.

In central and eastern Europe, the activity of intellectuals in service of national culture and movements for national liberation, took a major significance compared with western Europe, where the intellectual strata constituted only one of different social groups in competition with each-other for political influence and their activities were linked or conflicted with the classes of aristocracy, clergy, bureaucracy or the working classes. Besides, in most of Western Europe, universities were set-up before the founding of the nations-states, thus they were able to create a strong profile in society before being linked with the national imagination. Different was the case in Central and Eastern Europe where Universities were founded after the national awakening and the intellectuals had the monopoly of the codification of national languages, of the collection of cultural heritage and the inventing and spread of national imagination (Schopflin: 2000). Mostly, this was a characteristic of Balkan regions which were under the rule of the Ottomans. In this way can be explained the ambivalent positions of Albanian figures such as the Frasheri brothers, Hasan Prishtina or Ismail Qemali who used to be part of the Ottoman administration for several years and from the other hand some years after they became the main figures of Albanian national awakening. In this context, the position of Sami Frasheri was particularly emblematic: in his "Shqiperia cka qene, c'eshte e cdo te behet" he says that the most dangerous enemy for Albania are the turks, meanwhile in "Perhapja e Islamit" which was written originally in Arabic, he says that "gjuha turke eshte nje nder gjuhet me te embla" (Turkish is one of the most sweet languages) (Sami Frasheri: 1994). Also Hasan Prishtina in a total controversy with the ideal of the national awakening which was a movement addressed particularly against the Sublime Porte, in his memoirs writes that "Për kombin tonë shqiptarë, rrezik nuk përbëjn osmanët, por fqinjët tanë, grekët dhe serbët”/for our Albanian nation the greatest threat are not Ottomans, but our neighbors Greeks and Serbs (Hasan Prishtina: 1995). These examples show us that the imagined nation is much more difficult to come into life in the form of achieving the independence from a wide multi-national organization such as the Ottoman Empire, than inventing it as a process of reunion such as in Italy or Germany where there already exist some institutions that at a certain period can be politicized by diffusing national propaganda ${ }^{2}$ thus constructing the national imagination of the state. Sami Frasheri and Hasan Prishtina knew that a total rupture with the Ottoman Empire 
meant a total dissolution of the official nationalist propaganda which was also made possible by their political post inside the empire. As the multiple model of nationalism in which different parts struggle on which will infiltrate their political message (religion, ethnicity, language etc.) in the nationalist propaganda, education is also one of the fields of this struggle which will be shown in the following of this paper through analyzing the strive for the founding of the first school of Albanian language in Korça on 7 March 1887.

\section{The role of education in the construction of Albanian national identity}

Until the 1880s there didn't exist a single officially recognized Albanian-language school in all of the Albanian-populated territories. As Isa Blumi points out "this constituted an important disadvantage since schools were central to the development of intelligentsia that historically formed nation-states"(Schwandner-Sievers \& Fischer: 2002). Further it will be discussed the issue of whether Albanian schools constructed Albanian national identity or on the contrary they were constructed by the propagation of Albanian identity as a political tool. Two different scholars of Albanian national identity such as Denisa Kostovicova and Isa Blumi support the respective assumptions. Both of them agree that Albanian schools had a crucial impact in the construction of Albanian nationhood even because Albanian identity was invented, as we have already emphasized in the beginning of this paper, through the politicization of the spoken language. Since Albanian language started to being written it became an important factor of the national discourse through the publication of romantic poetries of the Frasheri brothers, Pashko Vasa and all the writers the Albanian renaissance.

Denisa Kostovicova in her article "Shkolla shqipe and nationhood: Albanians in the pursuit of education in the native language in interwar (1918-41) and post-war autonomy (1989-98) Kosovo" gives an analytical approach to the spread of Albanian language in Kosovo under the Yugoslavian state. In her analysis she remarks that Muslim religious schools ${ }^{1}$ in the interwar period and the "parallel system" in private school-houses ${ }^{2}$ during the post-war autonomy made possible the conservation of learning in Albanian language. ${ }^{3}$ Then she adds: "the so-called national courses gave meaning to Albanian nationhood" (Kostovicova: 2002). In her explanation she gives a clear description of the important role of schools in the construction of national myths, but she doesn't seem to give an answer to the question: How and in what circumstances Albanian-language schools were transformed into symbols of nationhood among the Albanians? In other terms: why Albanians in Kosovo considered it necessary to develop their national aspirations through schools of their mother tongue? In her approach, Kostovicova seems to sanctify the role of schools by transforming them from a political instrument for national identity into a final goal of national aspirations, as if nationhood was incorporated within the essential features of the demand to learn Albanian-language.

An answer seems to be provided from the other scholar, Isa Blumi, who appears to offer a more clear explanation to the problems with Kostovicova's approach. While speaking about the prominent figures that proclaimed Albanian national consciousness (Frasheri brothers etc.) he states that:"they were able to articulate cultural, political and spiritual concepts of a nation despite using Turkish, Arabic and Persian in clerical and secular schools of the Ottoman state, or studying under a decidedly hostile "Greek" system. This reality suggests that educational institutions and especially their curriculum and language of instruction did not constitute the key element in the development of Albanian nationalists"(Blumi: 2002). It is important to clarify that the rapid expansion of schools particularly in the northern Gheg regions only took place after the league of Prizren in 1878 (Rexhepagiq: 1970). His conception emphasizes that nationalist articulations of a sophisticated and geographically broad claim to a singular identity took place outside the context of an educational system that reinforced Albanian identities. This suggests that we should be looking elsewhere for other factors which helped articulate one's identity and the myths surrounding them. Furthermore he remarks that Austrian and Italian policy-making communities have used the development of education in northern and coastal areas of Albania to strengthen their imperial positions against the Ottoman Empire (Blumi: 2002). These historical facts are not relevant to the explanation of Kostovicova in Kosovo, but they show the importance of nationalist propaganda to manipulate the initial objective of the building of schools as imperial instruments by foreign powers, by transforming them in national fabrications of Albanian identities and myths.

\footnotetext{
1 While repressing Albanian secular schools, Serbian authorities condoned the work of private religious Muslim schools. This policy was driven by the same rationale as that of prohibiting secular schooling in Albanian - to undermine the feeling of Albanian national identity by stimulating the supremacy of collective identification based on religion.

${ }^{2}$ After the abolition of Albanian language in Universities, Albanian students collected their school and University Diplomas after years of studying in adapted rooms, shops, cellars, garages and attics (See Shkelzen Maliqi, Kosova: Separate worlds-reflections and analysis 1989- 1998, Peja: Dukagjini 1998, pp.113-17
} 
Blumi's explanation shows clearly that nationalism doesn't come together with schools of national language, but the later comes after the implementation of the national identity which doesn't include only the written languages, but a whole set of cultural forms which are transformed in a political doctrine through the mechanisms of nationalist discourse. Just like, as Hobsbawm emphasizes, "nationalism comes before nations" (Hobsbawm: 1992) we can also say nationalism comes before mass education and it's not mass education that produces nationalism, but it's the opposite. Blumi continues explaining that members of the Ottoman élite such as the Frasheri brothers, Ibrahim Temo and Ismail Qemali, had much to lose in the social changes occurring due to the imperial dynamics of the region (Blumi: 2002). Therefore it seems clear that Albanian national identity was a movement from above, i.e. the upper strata of the Ottomans were the first promoters of Albanian identity. The first secular school for boys opened in Korca in 1887 (Konitza: 1899) was only a consequence of the already existing struggle for Albanian identity, which nine years before the League of Prizren gave a crucial contribution.

The different ideas of Kostovicova and Blumi show us that there is no fundamental inner reason in the struggle for settingup Albanian language schools, that is to say the reason is not in the schools themselves, but in the political instruments that constructed schools as a breeding ground for national consciousness. Therefore we can say both of these positions are true on different contexts but both of them doesn't seem to grasp the basic idea of shifting identities. Even if Blumi seems to indicate that national schools were constructed be Albanian national identity to promote their language, he also seems to fall into an essentialist point of view while remaining attacked only on the political reasons of ethnically Albanian Ottoman elite. Even though this elite looks clearly interested in the invention of an Albanian national identity, that doesn't necessarily explain which elements of Albanian culture they transformed, nationalized and politicized to find the appropriate legitimacy among the ethnically Albanian population. Both of their viewpoints seem to analyze fixed identities, as if they were fixed once and for all respectively through the activity of romantic poets of the renaissance in Albania and the activity of informal learning during the interwar and post-autonomy period in Kosovo.

\section{Conclusions}

The idea of shifting identities can lead us to a much more clear analysis to the contemporary debates in Albanian public sphere regarding the revisiting of Albania's history by the Turkish authorities. It's obvious that history can't offer an objective truth, because as l've tried to show in this paper, the historical circumstances define the writing of history. Just after the independence Albanian history was written with a specific political mission, that is to say: a history of national liberation where the main purpose was the affirmation of national liberation through offering a subjective view of Ottoman's backwardness and brutality. Meanwhile, nowadays the turks are not anymore the enemies of our independence but an international partner in our foreign affairs. According to the present circumstances it looks clear that we can't have the same approach with an international partner as we had 100 years ago with the enemy from which we gained our liberation. Thus, as l've tried to explain in this paper, identity is a shifting category that can't be defined as a fixed notion but as a variety of elements. For example in the case of Kosovo interwar and post-autonomy period, Albanian schools were conceived as instruments of national identity, whereas before Albanian independence schools were simply tools in the hand of foreign imperial powers with the mission of helping the Christian minorities inside the Ottoman empire. In the rise of national consciousness it was the Albanian spoken language which was politicized 5 and transformed as the center of the invention of national identity. In other terms, on different periods we can identify ourselves through different elements of our identity, depending on which of these elements is more relevant to the historical context.

\section{References}

[1] Cohler, Albert.1988. "Montesquieu's comparative politics and the spirit of American Constitutionalism", University Press of Cansas, 71-5.

[2] Doja, Albert 2009. "Etniciteti, ndërtimi kombëtar dhe nacionalizmi në territorin etnik shqiptar: qasje antropologjike e konfliktit të marrëdhënieve ndëretnike", Polis 8, Tiranë p. 148-68.

[3] Frashëri, Sami 1994. "Përpjekja e heronjve në përhapjen e Islamit", Mihrani, Stamboll, Përkthyer nga Miftar Ajdini.

5 "Gjuha jone sa e mire, sa e bukur, sa me vlere" (our language so nice, so beautiful, so precious) (See Naim Frasheri) 
[4] Hobsbawm, Eric 1992. "Nations and nationalism since 1780: Programme, myth, reality" 2nd edition. Cambridge: Cambridge University Press.

[5] Konitza, Faik. 1899. "Mémoire sur le mouvement national albanais", Brussels: Albania.

[6] Kostovicova, Denisa 2002. "Shkolla shqipe and nationhood", London, UK: C. Hurst \& Co. Publishers, pp. 157171.

[7] Poulton, Hugh \& Taji-Farouki, Said 1997. Muslim Identity and the Balkan States, Hurst\& Company, London.

[8] Prishtina, Hasan 1995. Një shkurtim kujtimesh mbi kryengritjen shqyptare të vjetit 1912", Tiranë: Eurolindja

[9] Rexhepagiq, Jovan 1970. Zhvillimi $i$ arsimit dhe $i$ sistemit shkollor të kombësisë shqiptare në territorin e Jugosllavisë, Prishtina: Enti i Historisë së Kosovës.

[10] Schöpflin, George 2000. Nations, Identity, Power: The New Politics of Europe, London: Hurst \& Co.

[11] Schwandner- Sievers, Stephanie \& Fischer, Berndt 2002. Albanian Identities, Myth and History, London: Hurst \& Co.

[12] Sulstarova, Enis 2010. Në Pasqyrën e Oksidentit, Tiranë: Logos.

[13] Thiesse Anne-Marie 2004. Krijimi i Identiteteve Kombëtare: Evropa e Shekujve XVIII-XIX. Pejë: Dukagjini. 